\title{
Calon Tunggal dalam Pemilihan Kepala Daerah dan Wakil Kepala Daerah Perspektif Hukum Progresif
}

\author{
Allan Fatchan Gani Wardhana \\ Peneliti Pusat Studi Hukum Konstitusi (PSHK) FH UII \\ Jln. Lawu No. 1 Kotabaru Yogyakarta \\ allanfatchanganiw@yahoo.com
}

\begin{abstract}
Since its establishment until today, there have been many very progressive verdicts of Constitutional Court that can be used as the legal references for the acceleration of the legal reform in Indonesia. One of the verdicts of Constitutional Court is the one number 100/PUU-XIII/2015. This research is aimed to study the issues regarding first, whether the verdict of Constitutional Court Number 100/PUU-XIII/2015 on the single candidate in the election of the regional head and the deputy is included the progressive verdict? And second, what is the judicial implication of the Constitutional Court towards the nomination of the regional head and deputy? The research method used was the normative judicial method with the case approach. The results of the research concluded that first the verdict of the Constitutional Court Number 100/PUU-XIII/2015 is the progressive verdict. Second, the Verdict of the Constitutional Court has brought a judicial implication towards the nomination of the regional head and deputy that is by accommodating the single candidate in the implementation of the election of the regional head.
\end{abstract}

Key words: Single candidate, regional head election, progressive law

\begin{abstract}
Abstrak
Selama berdiri hingga sampai saat ini telah banyak putusan-putusan Mahkamah Konstitusi yang sangat progresif dan dapat menjadi acuan hukum bagi percepatan reformasi hukum di Indonesia. Salah satunya adalah Putusan Mahkamah Konstitusi Nomor 100/PUU-XIII/2015. Penelitian ini mengkaji permasalahan mengenai, pertama, apakah Putusan MK Nomor 100/PUU-XIII/2015 tentang calon tunggal dalam pemilihan kepala daerah dan wakil kepala daerah termasuk putusan yang progresif? Kedua, apa implikasi yuridis atas putusan MK tersebut terhadap pencalonan kepala daerah dan wakil kepala daerah? Metode penelitian yang digunakan adalah metode yuridis normatif dengan pendekatan kasus. Hasil penelitian menyimpulkan, pertama bahwa Putusan MK Nomor 100/PUU-XIII/2015 adalah putusan yang bersifat progresif. Kedua, Putusan MK tersebut telah membawa implikasi yuridis terhadap pencalonan kepala daerah dan wakil kepala daerah yaitu dengan mengakomodasi calon tunggal dalam pelaksanaan pilkada.
\end{abstract}

Kata Kunci : Calon tunggal, pemilihan kepala daerah, hukum progresif 


\section{Pendahuluan}

Keberadaan Mahkamah Konstitusi (MK) di Indonesia turut mewarnai dinamika ketatanegaraan serta diskursus hukum-hukum kenegaraan. Dalam praktiknya, dinamika ketatanegaraan itu telah, sedang, dan akan terus berkembang seiring dengan hadirnya lembaga MK sebagai pengawal UndangUndang Dasar Negara Republik Indonesia Tahun 1945 (UUD NRI 1945). Dapat dikatakan bahwa gagasan pembentukan MK tidak lain merupakan dorongan dalam penyelenggaraan kekuasaan dan ketatanegaraan Indonesia yang lebih baik. Paling tidak ada empat hal yang melatarbelakangi dan menjadi pijakan dalam pembentukan MK, yaitu: (1) sebagai implikasi dari paham konstitusionalisme; (2) mekanisme checks and balances; (3) penyelenggaraan negara yang bersih; dan (4) perlindungan Hak Asasi Manusia. ${ }^{1}$ Empat pijakan akademis tersebut berkorelasi dengan dorongan dan ekspektasi publik terhadap penyelenggaraan demokrasi dan penegakan hak asasi manusia sebagai cita-cita reformasi.

Ide pembentukan MK merupakan salah satu perkembangan pemikiran hukum ketatanegaraan modern yang muncul pada abad ke-20. Gagasan ini merupakan pengembangan dari asas-asas demokrasi di mana hak-hak politik rakyat dan hak-hak asasi merupakan tema dasar dalam pemikiran politik ketatanegaraan. Hak dasar tersebut dijamin secara konstitusional dalam sebuah hak-hak konstitusional warga negara dan diwujudkan secara institusional melalui lembaga negara yang melindungi hak konstitusional setiap warga. Lembaga yang dikonstruksi untuk menjamin hak konstitusional setiap warga tersebut, salah satunya adalah MK. Hal ini merupakan sebuah kebutuhan mendasar dari upaya perjuangan reformasi yang mencita-citakan terwujudnya negara demokrasi konstitusional. ${ }^{2}$

Selama MK berdiri hingga sampai saat ini, diakui sudah banyak kemajuankemajuan yang dicapai oleh institusi kehakiman yang lahir pada amandemen ketiga ini. MK sudah membuktikan sebagai institusi hukum yang dapat dipercaya

\footnotetext{
${ }^{1}$ Soimin \& Mashuriyanto, Mabkamah Konstitusi Dalam Sistem Ketatanegaraan Indonesia, UII Press, Yogyakarta, 2013, hlm. 59

${ }^{2}$ Ibid., hlm. 50-51
} 
dan terhormat (realible and honoured court) di Indonesia. Hal ini dibuktikan dengan banyaknya putusan-putusan MK yang sangat progresif dan dapat menjadi acuan hukum bagi percepatan reformasi hukum di Indonesia. ${ }^{3}$

Salah satu contoh Putusan MK yang bersifat progresif itu tersinyalir dalam Putusan MK-RI Nomor 100/PUU-XIII/2015 terkait pemilihan kepala daerah dengan hanya satu pasangan calon (calon tunggal). Pemohon dalam perkara ini ialah Effendi Ghazali (Pemohon I) dan Yayan Sakti Suryandaru (Pemohon II). Pemohon I adalah perseorangan warga Indonesia yang mempunyai hak untuk memilih serta merupakan warga negara Indonesia yang selalu aktif melaksanakan hak pilih dalam Pemilihan Umum dan Pemilihan Kepala Daerah. Adapun Pemohon II adalah perseorangan warga Indonesia yang merasa dirugikan oleh aturan yang menentukan "penundaan pilkada jika dalam suatu daerah terdapat kurang dari dua pasangan calon". Artinya dengan pilkada di suatu daerah yang hanya diikuti oleh calon tunggal, maka pilkada mengalami penundaan.

Terkait hal ini, Pemohon II merasa dirugikan karena menyebabkan pemilihan Kepala Daerah Kota Surabaya yang pada saat itu berpotensi mengalami penundaan. Penundaan Pemilihan Kepala Daerah mengakibatkan terhambatnya keputusan strategis dan penting dalam pembangunan daerah mengingat daerah tersebut dipimpin oleh seorang Pelaksana Tugas. Dalam permohonannya, Pemohon memohon kepada MK untuk menguji konstitusionalitas Pasal 49 ayat $(8)^{4}$

${ }^{3}$ Ni’matul Huda dan R. Nazriyah., Teori \& Pengujian Peraturan Perundang-undangan, Nusa Media, Bandung, 2011, hlm.146

${ }^{4}$ Dalam hal hasil penelitian sebagaimana dimaksud pada ayat (7) menghasilkan pasangan calon yang memenuhi persyaratan kurang dari 2 (dua) pasangan calon, tahapan pelaksanaan Pemilihan ditunda paling lama 10 (sepuluh) hari. 
dan ayat $(9)^{5}$, Pasal 50 ayat $(8)^{6}$ dan ayat $(9)^{7}$, Pasal 51 ayat $(2)^{8}$, Pasal 52 ayat $(2)^{9}$, serta Pasal 54 ayat (4) ${ }^{10}$, ayat (5) ${ }^{11}$ dan ayat (6) $)^{12}$ UU No. 8 Tahun 2015 terhadap:

- Pasal 28 D ayat (1) UUD 1945 Setiap orang berhak atas pengakuan, jaminan, perlindungan, dan kepastian hukum yang adil serta perlakuan yang sama di hadapan hukum.

- Pasal 28 I ayat (2) UUD 1945 Setiap orang berhak bebas dari perlakuan yang bersifat diskriminatif atas dasar apapun dan berhak mendapatkan perlindungan terhadap perlakuan yang bersifat diskriminatif itu.

- Pasal 27 ayat (1) UUD 1945 Segala warga negara bersamaan kedudukannya di dalam hukum dan pemerintahan dan wajib menjunjung hukum dan pemerintahan itu dengan tidak ada kecualinya.

- Pasal 27 ayat (2) UUD 1945 Tiap-tiap warga negara berhak atas pekerjaan dan penghidupan yang layak bagi kemanusiaan;

- Pasal 28 H ayat (1) UUD 1945 Setiap orang berhak hidup sejahtera lahir dan batin, bertempat tinggal, dan mendapatkan lingkungan hidup baik dan sehat serta berhak memperoleh pelayanan kesehatan;

- Pasal 28 C ayat (1) UUD 1945 Setiap orang berhak mengembangkan diri melalui pemenuhan kebutuhan dasarnya, berhak mendapat pendidikan dan memperoleh manfaat dari ilmu pengetahuan dan teknologi, seni dan budaya, demi meningkatkan kualitas hidupnya dan demi kesejahteraan umat manusia.

Pasal-pasal yang dimohonkan pengujian di atas, dalam implementasinya menjadi ruh dari UU No. 8 Tahun 2015 yang kemudian diturunkan dalam Peraturan Komisi Pemilihan Umum (PKPU) Nomor 12 Tahun 2015. Apabila diringkas, pokok argumentasi permohonan Pemohon berpusat pada masalah

${ }^{5}$ KPU Provinsi membuka kembali pendaftaran pasangan Calon Gubernur dan Calon Wakil Gubernur paling lama 3 hari setelah penundaan tahapan sebagaimana dimaksud pada ayat (8)

${ }^{6}$ Dalam hal hasil penelitian sebagaimana dimaksud pada ayat (7) menghasilkan pasangan calon yang memenuhi persyaratan kurang dari 2 pasangan calon, tahapan pelaksanaan pasangan Calon Bupati dan Calon Wakil Bupati serta pasangan Calon Walikota dan Calon Wakil Walikota pemilihan ditunda paling lama 10 hari

${ }^{7}$ KPU Kabupaten/Kota membuka kembali pendaftaran pasangan Calon Bupati dan Calon Wakil Bupati serta pasangan Calon Walikota dan Calon Wakil Walikota paling lama 3 hari setelah penundaan tahapan sebagaimana dimaksud pada ayat (8).

${ }^{8}$ Berdasarkan Berita Acara Penetapan sebagaimana dimaksudpada ayat (1), KPU Provinsi menetapkan paling sedikit 2 pasangan Calon Gubernur dan Calon Wakil Gubernur dengan Keputusan KPU Provinsi.

9 Berdasarkan Berita Acara Penetapan sebagaimana dimaksud pada ayat (1), KPU Kabupaten/Kota menetapkan paling sedikit 2 pasangan Calon Bupati dan Calon Wakil Bupati serta pasangan Calon Walikota dan Calon Wakil Walikota dengan Keputusan KPU Kabupaten/Kota

${ }^{10}$ Dalam hal pasangan berhalangan tetap sejak penetapan pasangan calon sampai pada saat dimulainya hari Kampanye sehingga jumlah pasangan calon kurang dari 2 orang, KPU Provinsi dan KPU Kabupaten/Kota membuka kembali pendaftaran pengajuan pasangan calon paling lama 7 hari

11 Dalam hal pasangan calon berhalangan tetap pada saat dimulainya kampanye sampai hari pemungutan suara dan terdapat 2 pasangan calon atau lebih, tahapan pelaksanaan Pemilihan dilanjutkan dan pasangan calon yang berhalangan tetap tidak dapat diganti serta dinyatakan gugur.

12 Dalam hal pasangan calon berhalangan tetap pada saat dimulainya Kampanye sampai hari pemungutan suara pasangan calon kurang dari 2 orang, tahapan pelaksanaan Pemilihan ditunda paling lama 14 hari. 
terganggunya atau bahkan tidak dapat diselenggarakannya pemilihan kepala daerah dan wakil kepala daerah sebagaimana dijadwalkan disebabkan oleh adanya ketentuan dalam norma Undang-Undang yang dimohonkan pengujian yang mempersyaratkan paling sedikit ada dua pasangan calon kepala daerah dan wakil kepala daerah. ${ }^{3}$ Pemohon dalam alasannya mendalilkan bahwa warga negara yang tinggal di daerah yang pemilihan kepala daerahnya hanya memiliki satu pasangan calon terdaftar di KPUD, mengalami perlakuan diskriminatif dan tidak mendapat kepastian hukum yang adil, dibandingkan dengan warga negara yang tinggal di daerah yang Pemilihan Kepala Daerahnya memiliki lebih dari satu pasangan calon terdaftar di KPUD dan tentunya mengalami kerugian hak memilih, yang tidak hanya dapat tertunda satu kali, namun dapat pula tertunda berkali-kali dalam kondisi tidak menentu.

Terhadap perkara ini, MK memutuskan bahwa jika dalam suatu daerah terdapat Calon kepala daerah dan calon wakil kepala daerah dengan hanya satu pasang (calon tunggal), maka harus tetap dilaksanakan dengan syarat tertentu. Dalam putusan MK tersebut, tersinyalir benih-benih hukum progresif didalamnya. MK memberikan jalan keluar dan terobosan hukum bagi pelaksanaan pilkada dengan hanya satu pasangan calon, padahal sebelumnya UU No. 8 Tahun 2015 tidak mengatur terkait pilkada dengan hanya satu pasangan calon.

\section{Rumusan Masalah}

Berdasarkan latar belakang di atas, rumusan masalah yang menjadi fokus penelitian ini sebagai berikut. Pertama, apakah putusan Mahkamah Konstitusi Nomor 100/PUU-XIII/ 2015 tentang calon tunggal dalam pemilihan kepala daerah dan wakil kepala daerah termasuk putusan yang progresif? Kedua, apa implikasi yuridis atas putusan MK tersebut terhadap pencalonan kepala daerah dan wakil kepala daerah?

13 Putusan MK-RI Nomor 100/PUU-XIII/2015 hlm. 37-38 


\section{Tujuan Penelitian}

Adapun penelitian ini bertujuan untuk mengetahui : pertama, untuk mengetahui progresivitas putusan Mahkamah Konstitusi Nomor 100/PUUXIII/2015 terkait calon tunggal dalam pemilihan kepala daerah dan wakil kepala; kedua, implikasi yuridis atas putusan Mahkamah Konstitusi Nomor 100/PUUXIII/2015 terhadap pencalonan kepala daerah dan wakil kepala daerah.

\section{Metode Penelitian}

Jenis Penelitian ini adalah penelitian hukum normatif, karena peneliti melakukan penelitian dengan studi literatur, peraturan perundang-undangan, dan putusan Mahkamah Konstitusi yang berhubungan dengan objek penelitian guna mencari jawaban atas masalah yang hendak diteliti. Sumber data yang digunakan dalam penelitian ini adalah bahan-bahan hukum yang terdiri dari bahan hukum primer, bahan hukum sekunder, dan bahan hukum tersier. Penelitian ini menggunakan teknik pengumpulan bahan hukum melalui metode penelitian library research yang terdiri dari buku-buku, jurnal ilmiah, media massa dan internet serta referensi lain yang relevan. Pendekatan dalam penelitian ini adalah pendekatan kasus (case approach). Penelitian ini menggunakan teknik analisis bahan hukum deskriptif kualitatif yaitu pengelompokan dan penyesuaian data-data yang diperoleh dari suatu gambaran sistematis yang didasarkan pada teori dan pengertian hukum yang terdapat dalam ilmu hukum untuk menghasilkan kesimpulan yang signifikan dan ilmiah yang dapat menjawab rumusan masalah penelitian.

\section{Hasil Penelitian dan Pembahasan}

\section{Hukum Progresif dan Indikator Putusan MK yang Progresif}

Progresif itu sendiri secara etimologi berasal dari kata progess dari bahasa Inggris yang berarti kemajuan. Jika kata 'hukum' digabung dengan kata 'progresif', maka bermakna bahwa hukum hendaknya mampu mengikuti perkembangan 
zaman agar mampu melayani kepentingan masyarakat berdasarkan aspek moralitas sumberdaya para penegak hukum. ${ }^{14}$ Itulah yang kemudian disebut dengan hukum progresif. Dikaitkan dengan putusan MK yang progresif, tentu tidak bisa langsung dimaknai bahwa putusan MK yang progesif itu ialah putusan yang mampu mengikuti perkembangan zaman dan realitas ketatanegaraan di Indonesia. Putusan MK yang progresif tidak cukup hanya didasarkan asumsi bahwa putusannya mengikuti perkembangan zaman, akan tetapi harus dilengkapi dengan indikator-indikator dari konsep hukum progresif itu sendiri.

Hal penting dalam suatu putusan MK yang progresif ini, bahwa putusan MK yang bersifat progresif bertumpu pada kualitas aparat penegak hukum terutama hakim konstitusi. Hal ini bisa dijadikan sebuah alternatif untuk mengatasi problem ketidakadilan karena melihat sangat sulit untuk menciptakan hukum yang benar-benar mencerminkan keadilan dalam masyarakat. Dalam kenyataannya, pembentukan hukum seringkali tidak lepas dari campur tangan penguasa. Seringkali penguasa mengarahkan hukum untuk tujuan pribadi, seperti mempertahankan kekuasaan, memperkaya diri sendiri, menaikkan pangkat dan lain sebagainya, sehingga hukum tidak lagi mencerminkan manfaat bagi masyarakat. ${ }^{15}$ Dalam kondisi yang demikian ini, maka aparat penegak hukum dalam hal ini para hakim konstitusi harus berani untuk tampil dengan keluar dari hukum-hukum yang normatif yang cenderung tidak mencerminkan keadilan bagi masyarakat.

Dalam hukum progresif, perubahan tidak lagi pada peraturan, tetapi pada kreativitas pelaku hukum mengaktualisasi hukum dalam ruang dan waktu yang tepat. Aksi perubahan pun bisa segera dilakukan tanpa harus menunggu perubahan peraturan (changing the law), karena pelaku hukum progresif dapat melakukan pemaknaan progresif terhadap peraturan yang ada. Menghadapi suatu aturan, meskipun aturan itu tidak aspiratif misalnya, aparat penegak hukum yang progresif tidak harus menepis keberadaan aturan itu. Ia bisa setiap kali melakukan interpretasi secara baru terhadap aturan tersebut untuk memberi keadilan dan

14 Satjipto Rahardjo, Hukum Progresif, Sebuah Sintesa Hukum Indonesia, Genta Press, Yogyakarta, 2009, hlm.

${ }^{15}$ Mahrus Ali, Membumikan Hukum Progresif, Aswaja Pressindo, Yogyakarta, 2013, hlm. 8 
kebahagiaan kepada pencari keadilan. ${ }^{16}$ Maka, disinilah hakim konstitusi dituntut untuk melakukan kreasi peraturan manakala peraturan yang ada nyata-nyata tidak mampu menjawab tantangan zaman. Penafsiran yang dilakukan oleh hakim menjadi suatu hal yang niscaya.

Berdasarkan kosmologinya, kehadiran hukum progresif bukanlah sesuatu yang kebetulan, bukan sesuatu yang lahir tanpa sebab, dan juga bukan sesuatu yang jatuh dari langit. Hukum progresif adalah bagian dari proses pencarian kebenaran yang tidak pernah berhenti. Hukum progresif yang dapat dipandang sebagai konsep yang sedang mencari jati diri bertolak dari realitas empiris tentang bekerjanya hukum di masyarakat, berupa ketidakpuasaan dan keprihatinan terhadap kinerja dan kualitas penegak hukum di Indonesia. Hukum tidak hanya dianggap selesai setelah tersusun sebagai peraturan perundang-undangan dengan kalimat-kalimat yang sangat rapi dan sistematis, namun hukum harus selalu mengalami proses pemaknaan sebagai sebuah pendewasaan atau pematangan. Dengan proses inilah, maka hukum dapat menampakkan jati dirinya sebagai sebuah ilmu, yaitu selalu berproses untuk mencari kebenaran. Dalam pengertian ini, hukum juga harus dilihat secara utuh menyeluruh yang menekankan pada sifat substantif dan transendental dengan mendasarkan pada fakta sosial yang tidak lepas dari nilai-nilai agama, etik dan moral, bukan hanya dalam wujud normanorma tertulis. ${ }^{17}$

Kehadiran hukum progresif berangkat dari asumsi dasar bahwa "hukum adalah untuk manusia" dan "hukum selalu dalam proses untuk menjadi". Berkaitan dengan dua asumsi tersebut, Satjipto Rahardjo menyatakan bahwa :18

"Hukum adalah institusi yang secara terus menerus membangun dan mengubah dirinya menuju kepada tingkat kesempurnaan yang lebih baik. Kualitas kesempurnaan di sini bisa diverifikasi ke dalam faktor-faktor keadilan, kesejahteraan, kepedulian kepada rakyat dan lain-lain. Inilah hakikat "hukum yang selalu dalam proses menjadi". Hukum tidak ada untuk hukum itu sendiri, tetapi untuk manusia."

${ }^{16}$ Ibid., hlm. 23

${ }_{17}$ Turiman, "Memahami Hukum Progresif Satjipto Rahardjo dalam Paradigma Thawaf” yang dikutip dalam Mahrus Ali, Ibid., hlm. 7

${ }^{18}$ Ibid., hlm. 128 
Karena hukum progresif berangkat dari asumsi hukum itu untuk manusia dan hukum selalu dalam proses menjadi, maka penegak hukum seharusnya bukan hanya sekedar memahami hukum positif yang selama ini berlaku saja, tetapi bagaimana seorang penegak hukum itu mampu mengangkat nilai-nilai hukum yang bermuara kepada sebuah keadilan yang sesungguhnya, bukan hanya keadilan yang berdasarkan rentetan kata-kata atau kalimat peraturan perundangundangan saja, tetapi lebih kepada keadilan yang nyata. ${ }^{19}$ Manusia selaku aktor penting dan utama di belakang kehidupan hukum, tidak hanya dituntut mampu menciptakan dan menjalankan hukum (making the law), tetapi juga keberanian mematahkan dan merobohkannya (breaking the law), manakala hukum tidak sanggup menghadirkan roh dan substansi keberadaannya, yakni menciptakan keharmonisan, kedamaian, ketertiban, dan kesejahteraan masyarakat. ${ }^{20}$ Kalau boleh diringkas, hukum progresif itu sesungguhnya sederhana, yaitu melakukan pembebasan, baik dalam cara berpikir maupun bertindak dalam hukum, sehingga mampu membiarkan hukum itu mengalir saja untuk menuntaskan tugasnya mengabdi kepada manusia dan kemanusiaan. ${ }^{21}$

Ide penegakan hukum progresif menghendaki penegakan hukum tidak sekadar menjalankan peraturan perundang-undangan, tetapi menangkap kehendak hukum masyarakat. Oleh karena itu, ketika suatu peraturan dianggap membelenggu penegakan hukum, maka dituntut kreativitas dari penegak hukum itu sendiri agar mampu menciptakan produk hukum yang mengakomodasi kehendak masyarakat yang bertumpu pada nilai-nilai yang hidup di masyarakat. Oleh sebab itu, ide penegakan hukum progresif merupakan letupan dari situasi penegakan hukum yang stagnan atau mengalami kemandekan. ${ }^{22}$

Berdasarkan uraian di atas, peneliti merumuskan indikator-indikator bahwa putusan MK yang progresif berangkat dari dua asumsi, yaitu "hukum adalah untuk manusia" dan "hukum dalam proses terus menjadi" dengan indikator :

Pertama, hukum harus peka terhadap perubahan yang terjadi di masyarakat baik lokal, nasional, maupun global sehingga Putusan MK cenderung tidak

\footnotetext{
${ }^{19}$ Ibid., hlm. 91

${ }^{20}$ Satjipto Rahardjo, Penegakan Hukum Progresif, Penerbit Buku Kompas, Jakarta, 2010, hlm. vii

${ }^{21}$ Ibid.

22Ibid.
} 
positivistik. Berhadapan dengan perubahan-perubahan yang terjadi dalam masyarakat, hukum progresif terpanggil untuk tampil melindungi rakyat menuju kepada ideal hukum. Hukum bekerja dengan cara memancangi perbuatan seseorangan atau hubungan antara orang-orang dalam masyarakat. Untuk keperluan pemancangan tersebut, maka hukum menjabarkannya pekerjaannya dalam berbagai fungsinya, yaitu: (1) pembuatan norma-norma, baik yang memberikan peruntukan maupun yang menentukan hubungan antara orang dengan orang; (2) penyelesaian sengketa-sengketa; (3) menjamin kelangsungan kehidupan masyarakat, yaitu dalam hal terjadi perubahan-perubahan. Hukum, dengan demikian, digolongkan sebagai sarana untuk melakukan kontrol sosial, yaitu suatu proses mempengaruhi orang-orang untuk bertingkah laku sesuai dengan harapan masyarakat. Oleh hukum, kontrol sosial tersebut dijalankan dengan menggerakkan berbagai aktivitas, yang melibatkan penggunaan dari kekuasaan negara sebagai suatu lembaga yang diorganisasi secara politik, melalui lembaga-lembaga yang dibentuknya. Hukum sebagai sarana kontrol sosial tidak hanya ditujukan kepada pemecahan masalah yang ada, melainkan berkeinginan untuk menimbulkan perubahan-perubahan dalam tingkah laku anggota masyarakat. $^{23}$

Hukum progresif ini sebenarnya merupakan pertentangan dari faham positivistik yang dianut oleh hampir semua aparat penegak hukum, terutama hakim di Indonesia. Paham positivistik ini selalu berpegang teguh kepada hukum tertulis (law in book), karena meyakini bahwa keadilan dapat terwujud dengan menerapkan hukum tertulis. Dengan demikian, seolah keadilan didefinisikan dalam hukum tertulis. Pendefinisian apa yang adil dan tidak dalam hukum tertulis merupakan bentuk "kekerasan keadilan" yang mempersempit serta mensubjektivikasi makna keadilan. Hukum progresif bertolak belakang dari faham positivistik yang selalu tunduk pada aturan tertulis. Hukum progresif menjadikan ketulusan dan kejujuran sebagai mahkota penegakan hukum. Keadilan menjadi tujuan akhir dari proses penegakan hukum. Ajaran hukum progresif ini mengutamakan pada sikap empati, kepedulian, dan dedikasi dari para aparat

${ }^{23}$ Satjipto Rahardjo, Hukum dan Perubahan Sosial : Suatu Tinjauan Teoretis Serta Pengalaman-Pengalaman Di Indonesia, Cet ke-3, Genta Publishing, Yogyakarta, 2009, hlm. 112 
penegak hukum karena merekalah ujung tombak penegakan hukum. ${ }^{24}$ Madzab positivistik menempatkan Pengadilan hanya sebagai corong undang-undang atau sebagai tempat dimana penegak hukum menerapkan pasal-pasal tertulis.

Kedua, menolak dan mematahkan status quo, sehingga Putusan MK cenderung menegasikan, mengganti, membebaskan hukum yang mandek karena tidak mampu melayani lingkungan yang berubah. Menolak dan mematahkan status quo berarti menolak untuk mempertahankan norma-norma yang telah ada tanpa ada kritik apapun, sehingga norma-norma tersebut selalu diterapkan apa adanya dalam keadaan dan kondisi apapun. Hampir tidak ada usaha untuk melakukan perbaikan, yang ada hanya menjalankan hukum seperti apa adanya dan secara biasa-biasa saja (business as usual). Hakim lebih cenderung mengambil posisi aman dengan menjalankan status quo tanpa berpikir untuk melakukan perubahan dan pembaruan. ${ }^{25}$ Indikator yang kedua ini sangat erat kaitannya dengan indikator pertama.

Hukum progresif dan ilmu hukum progresif tidak bisa disebut sebagai suatu tipe hukum yang khas dan selesai (distinct type and a finite scheme), melainkan lebih merupakan gagasan yang mengalir, yang tidak mau terjebak ke dalam status quo, sehingga mandek (stagnant). Hukum progresif selalu ingin setia pada asas besar, "hukum adalah untuk manusia". Hukum progresif bisa diibaratkan sebagai papan penunjuk yang selalu memeringatkan, hukum harus terus-menerus merobohkan, mengganti, membebaskan hukum yang mandek, karena tidak mampu melayani lingkungan yang berubah. Itulah sebabnya hukum selalu mengalir, karena kehidupan manusia memang penuh dengan dinamika dan berubah dari waktu ke waktu. Kehidupan manusia tersebut tidak bisa diwadahi secara ketat ke dalam satu atau lain bagan yang selesai dan tidak boleh diubah (finite scheme). Bagan tersebut harus terbuka, karena bukan manusia untuk hukum, melainkan sebaliknya. ${ }^{26}$

Ketiga, hukum bukan institusi yang mutlak dan final, karena hukum selalu dalam proses menjadi sehingga Putusan MK cenderung terdapat adanya

${ }^{24}$ Mahrus Ali, Membumikan..., Op. Cit., hlm. 11

${ }_{25}$ Satjipto Rahardjo, Membedah Hukum Progresif, Editor I Gede A.B Wiranata, Joni Emirzon, Firman Muntaqo, Penerbit Buku Kompas, Jakarta, 2006, hlm. 115

${ }^{26}$ Satjipto Rahardjo, Hukum Progresif.., Op. Cit., hlm. 84 
pemaknaan yang kreatif terhadap peraturan yang ada, tanpa harus menunggu perubahan peraturan. Tidak mengherankan bila eksistensi hukum progresif bertumpu pada manusia, membawa konsekuensi pentingnya kreativitas. Kreativitas dalam konteks penegakan hukum selain untuk mengatasi ketertinggalan hukum, mengatasi ketimpangan hukum, juga dimaksudkan untuk membuat terobosan-terobosan hukum. Terobosan hukum inilah yang diharapkan dapat mewujudkan tujuan kemanusiaan melalui bekerjanya hukum, yang menurut Satjipto Rahardjo diistilahkan dengan hukum yang membuat bahagia. ${ }^{27}$

Terobosan hukum sesungguhnya bukan sesuatu hal yang baru di dunia hukum, apalagi pada saat hukum telah mengalami kebekuan jika dihadapkan dengan realitas persoalan hukum masyarakat. Terobosan oleh institusi peradilan merupakan konsekuensi dari karakteristik norma hukum positif yang bersifat statis dihadapkan dengan kehidupan masyarakat dan praktik berhukum yang dinamis. Karena itu, terobosan hukum sebenarnya suatu kewajaran. Namun, hal itu menjadi diskursus hangat karena kondisi hukum di Indonesia yang cenderung stagnan. Terobosan hukum justru harus ada jika dilihat dari tiga aspek yaitu, (1) tujuan tertinggi dari hukum adalah untuk mewujudkan keadilan. Meski demikian, hukum dan keadilan memang tidak selalu sama; (2) dalam pembentukan hukum selalu terdapat keterbatasan terutama dalam memperkirakan perkembangan praktik dan peristiwa hukum yang akan terjadi di masa depan. Manifestasi keadilan yang dirumuskan dalam norma hukum juga terbatas pada keadilan yang dipahami dan dirasakan oleh pembentuk hukum saat itu. Penerapannya, ada kemungkinan jika suatu norma hukum diterapkan untuk kasus tertentu justru menimbulkan ketidakadilan. Pada titik ini tidak tepat kiranya jika hakim harus selalu berposisi corong UU, melainkan harus pula bertindak sebagai pembentuk hukum. Hal ini menjadi salah satu faktor yang mendorong konvergensi antar sistem atau tradisi hukum di semua negara, antara civil law dan common law; (3) peran hakim sebagai pembentuk hukum dengan sendirinya akan menguat pada saat norma hukum positif masih dalam tahap awal perkembangan. Inilah yang menjadi faktor ketiga berbagai terobosan hukum MK.28 Hukum yang diciptakan

${ }^{27}$ Mahrus Ali, Membumikan .., Op. Cit., hlm. 24

${ }^{28}$ Soimin \& Mashuriyanto, Mabkamah..., Op. Cit., hlm. 194 
oleh MK melalui putusan mengutamakan keadilan substantif (social justice) dibanding formal-prosedural (legal formal). Paradigma keadilan substantif bisa saja menyimpang dari UU kalau pelaksanaan UU itu menimbulkan ketidakadilan.

Dalam hukum progresif, proses perubahan tidak lagi berpusat pada peraturan, akan tetapi pada kreativitas pelaku hukum mengaktualisasikan hukum dalam ruang dan waktu yang tepat. Para pelaku hukum progresif dapat melakukan perubahan dengan melakukan pemaknaan yang kreatif terhadap peraturan yang ada, tanpa harus menunggu perubahan peraturan. Peraturan yang buruk tidak harus menjadi penghalang bagi para pelaku hukum progresif untuk menghadirkan keadilan bagi rakyat dan pencari keadilan, karena mereka dapat melakukan interpretasi secara baru setiap kali terhadap suatu peraturan. ${ }^{29}$

\section{Progresivitas Putusan MK-RI Nomor 100/PUU-XIII/2015}

Putusan MK-RI Nomor 100/PUU-XIII/2015 merupakan salah satu putusan yang turut mewarnai dinamika ketatanegaraan di Indonesia. Putusan ini berangkat dari fenomena adanya calon tunggal dalam pilkada yang kemudian berbuntut pada pengujian konstitusionalitas UU No. 8 Tahun 2015. Dalam pengujian konstitusionalitas itu, Pemohon menilai bahwa ketentuan dalam norma undangundang yang dimohonkan pengujian yang mempersyaratkan paling sedikit ada dua pasangan calon kepala daerah dan wakil kepala daerah harus dikaji ulang, terutama jika dibenturkan dengan realitas adanya calon tunggal dalam pilkada.

Jika diperhatikan secara seksama, rumusan norma UU No. 8 Tahun 2015 yang dimohonkan pengujian sebagaimana telah diuraikan atas, secara sistematis tampak nyata kalau pembentuk undang-undang, di satu pihak, bermaksud bahwa dalam kontestasi Pemilihan Kepala Daerah setidak-tidaknya harus ada dua pasangan calon, di lain pihak, sama sekali tidak memberikan jalan keluar seandainya syarat paling kurang dua pasangan calon tersebut tidak terpenuhi. Dengan demikian, akan ada kekosongan hukum manakala syarat paling kurang dua pasangan calon tersebut tidak terpenuhi di mana kekosongan hukum

${ }^{29}$ M. Syamsudin, "Kecenderungan Paradigma Berfikir Hakim Dalam Memutus Perkara Korupsi”, Jurnal Media Hukum, Vol. 15, No. 2, Tahun 2008, hlm. 202 
demikian akan berakibat pada tidak dapat diselenggarakannya Pemilihan Kepala Daerah.

Dalam mengatasi kebuntuan tersebut, KPU mengeluarkan Peraturan Komisi Pemilihan Umum Nomor 12 Tahun 2015. Dalam Pasal 54 ayat (5) Peraturan KPU Nomor 12/2015 tersebut menyatakan, "Dalam hal sampai dengan berakhirnya pembukaan kembali masa pendaftaran hanya terdapat 1 (satu) Pasangan Calon atau tidak ada Pasangan Calon yang mendaftar sebagaimana dimaksud pada ayat (1), KPU Provinsi/KIP Aceh atau KPU/KIP Kabupaten/Kota menetapkan keputusan penundaan seluruh tahapan dan Pemilihan diselenggarakan pada Pemilihan serentak berikutnya. Jika ditunda dalam pemilihan serentak berikutnya, maka jika dalam suatu daerah hanya ada satu pasangan calon, pelaksanaan pilkada ditunda dari yang semula dilaksanakan pada tahun 2015 menjadi dilaksanakan pada bulan Februari tahun 2017.

Terhadap penyelesaian kebuntuan dari KPU itu, MK berpendapat bahwa Peraturan KPU itu tidak menyelesaikan persoalan tidak terlaksananya hak rakyat untuk dipilih dan memilih karena dua alasan. Pertama, penundaan ke Pemilihan serentak berikutnya sesungguhnya telah menghilangkan hak rakyat untuk dipilih dan memilih pada Pemilihan serentak saat itu. Kedua, andaikatapun penundaan demikian dapat dibenarkan, quod non, tetap tidak ada jaminan bahwa pada Pemilihan serentak berikutnya itu, hak rakyat untuk dipilih dan memilih akan dapat dipenuhi. Hal itu dikarenakan penyebab tidak dapat dipenuhinya hak rakyat untuk dipilih dan memilih itu tetap ada, yaitu ketentuan yang mempersyaratkan paling sedikit adanya dua Pasangan Calon dalam kontestasi Pemilihan Kepala Daerah. ${ }^{30}$

Akhirnya, melalui putusannya, MK memberikan jalan keluar bagi daerah yang hanya ada satu pasangan calon dengan mengabulkan permohonan Pemohon untuk sebagian. MK menyatakan bahwa Pemilihan Kepala Daerah yang hanya diikuti oleh satu pasangan calon kepala daerah dan wakil kepala daerah tetap dilaksanakan dengan catatan bahwa harus diusahakan terlebih dulu dengan sungguh-sungguh untuk terpenuhi syarat paling sedikit dua pasangan calon

${ }^{30}$ Putusan MK-RI Nomor 100..., Op. Cit., hlm. 42 
kepala daerah dan wakil kepala daerah. ${ }^{31}$ Yang dimaksud dengan "telah diusahakan dengan sungguh-sungguh" adalah telah dilaksanakan ketentuan dalam Pasal 49 ayat (1) sampai dengan ayat (9) UU No. 8 Tahun 2015 (untuk pemilihan Gubernur/Wakil Gubernur) dan ketentuan Pasal 50 ayat (1) sampai dengan ayat (9) UU No. 8 Tahun 2015 (untuk pemilihan Bupati/Wakil Bupati dan Walikota/Wakil Walikota).

Bahwa Pemilihan Kepala Daerah yang hanya diikuti oleh satu pasangan calon kepala daerah dan wakil kepala daerah dilakukan dengan memberikan kesempatan kepada rakyat (pemilih) untuk menyatakan "Setuju" atau "Tidak Setuju" dalam surat suara yang didesain sedemikian rupa sehingga memungkinkan rakyat (pemilih) untuk menyatakan pilihan "Setuju" atau "Tidak Setuju" dimaksud. Apabila pilihan "Setuju" memperoleh suara terbanyak maka pasangan calon kepala daerah dan wakil kepala daerah dimaksud ditetapkan sebagai kepala daerah dan wakil kepala daerah terpilih, sedangkan apabila pilihan "Tidak Setuju" memperoleh suara terbanyak maka pemilihan ditunda sampai Pemilihan Kepala Daerah serentak berikutnya. ${ }^{32}$

Atas putusan MK tersebut, komisioner KPU, Ida Budhiati, mengatakan bahwa dalam putusan MK disebutkan pemilihan pasangan calon tunggal dapat dilakukan apabila telah melampaui kegiatan sebagaimana dimaksud pada ketentuan Pasal 49 atau Pasal 50 UU Pilkada. Ketentuan tersebut dianggap sudah sesuai dengan fakta hukum penyelenggaraan pilkada di tiga daerah yang hanya memiliki pasangan calon tunggal. Ketiga daerah tersebut, yaitu Blitar, Jawa Timur; Timor Tengah Utara, Nusa Tenggara Timur; dan Tasikmalaya, Jawa Barat, sudah melakukan pendaftaran dan menghasilkan hanya ada satu pasangan calon. KPU sempat memutuskan pelaksanaan pemungutan suara di ketiga kabupaten tersebut ditunda ke pilkada serentak 2017. Akhirnya setelah melalui rapat pleno, diputuskan bahwa putusan MK tersebut akan dilaksanakan pada pilkada serentak 2015.33 Dalam perkembangannya, ketiga daerah yaitu Blitar, Timor Tengah Utara,

${ }^{31}$ Ibid., hlm. 44

${ }^{32}$ Ibid., hlm. 45

${ }^{33 h}$ http://print.kompas.com/baca/2015/09/30/Kejar-Pilkada-2015\%2c-Tiga-Kabupaten-dengan-CalonTu (diakses 28 Maret 2016) 
dan Tasikmalaya tetap menggelar pilkada dengan hanya satu pasangan calon. Hasilnya, calon tunggal dalam pilkada di ketiga daerah tersebut justru menang.

Ditinjau dari perspektif hukum progresif, putusan MK ini termasuk putusan yang progresif. Indikasinya ialah, pertama, putusan MK tidak positivistik dan sekaligus menunjukkan bahwa hukum harus peka terhadap perubahan yang terjadi di masyarakat. Fenomena calon tunggal yang sempat muncul di beberapa daerah yang menyelenggarakan pilkada tidak terprediksi dalam UU No. 8 Tahun 2015. Politik hukum UU No. 8 Tahun 2015 mengkonstruksikan bahwa dalam pilkada minimal diikuti oleh dua pasangan calon. Jika hanya ada satu pasangan calon, maka berdasarkan PKPU 12/2015, pilkada ditunda dengan jadwal yang semula dilaksanakan pada 2015 menjadi dilaksanakan 2017. Melihat fenomena adanya calon tunggal dalam pilkada, MK kemudian memberikan terobosan hukum yang pada intinya pilkada harus tetap dilaksanakan meskipun dengan hanya satu pasangan calon.

Kedua, MK menolak dan mematahkan status quo dengan cara menegasikan Pasal 49, Pasal 50, Pasal 51, dan Pasal 52 UU 8/2015 dan diberi makna baru oleh MK. Sikap MK dalam menolak dan mematahkan status quo ini terlihat dalam pertimbangan hukumnya yang menyatakan : ${ }^{34}$

...telah menjadi pendirian Mahkamah bahwa sebagai pengawal Konstitusi Mahkamah tidak boleh membiarkan terjadinya pelanggaran terhadap hakhak konstitusional warga negara, sebagaimana salah satunya tercermin dalam pertimbangan hukum Putusan Nomor 1/PUU-VIII/2010 yang menegaskan, antara lain, bahwa "Mahkamah, sesuai dengan kewenangan konstitusionalnya, tidak akan membiarkan adanya norma dalam Undang-Undang yang tidak konsisten dan tidak sesuai dengan amanat perlindungan konstitusional yang dikonstruksikan oleh Mahkamah" (vide Putusan Mahkamah Nomor 1/PUU- VIII/2010, bertanggal 24 Februari 2011), lebih-lebih apabila pelanggaran demikian bersangkut-paut dengan pelaksanaan kedaulatan rakyat yang membawa akibat luas sebab berdampak pada terganggunya pelaksanaan pemerintahan, dalam hal ini pemerintahan daerah. Dalam keadaan demikian, Mahkamah dituntut untuk memberikan jalan keluar dari kebuntuan yang ditimbulkan oleh UU 8/2015 yang dimohonkan pengujian ini.

${ }^{34}$ Putusan MK-RI Nomor 100..., Op. Cit., hlm. 41 
Terjadinya keadaan sebagaimana diuraikan di atas, MK berusaha untuk menemukan cara agar hak konstitusional warga negara yang sekaligus merupakan wujud pelaksanaan kedaulatan rakyat itu, dalam hal ini hak untuk dipilih dan memilih dalam Pemilihan Kepala Daerah, tetap terpenuhi tanpa tersandera oleh syarat paling sedikit adanya dua pasangan calon kepala daerah dan wakil kepala daerah. Bagaimanapun prinsip kedaulatan rakyat itu harus dijunjung tinggi.

Ketiga, terdapat pemaknaan yang kreatif atas putusan MK tersebut. Dalam putusannya, MK memberikan makna terhadap Pasal 49 ayat (9), Pasal 50 ayat (9), Pasal 51 ayat (2), dan Pasal 52 ayat (2). Adapun bunyi pasalnya menjadi berikut :

Pasal 49 ayat (9) : KPU Provinsi membuka kembali pendaftaran pasangan Calon Gubernur dan Calon Wakil Gubernur paling lama 3 (tiga) hari setelah penundaan tahapan sebagaimana dimaksud pada ayat (8), termasuk menetapkan 1 (satu) pasangan Calon Gubernur dan Calon Wakil Gubernur peserta Pemilihan dalam hal setelah jangka waktu 3 (tiga) hari dimaksud terlampaui namun tetap hanya ada 1 (satu) pasangan Calon Gubernur dan Calon Wakil Gubernur"

Pasal 50 ayat (9) : KPU Kabupaten/Kota membuka kembali pendaftaran pasangan Calon Bupati dan Calon Wakil Bupati serta pasangan Calon Walikota dan Calon Wakil Walikota paling lama 3 (tiga) hari setelah penundaan tahapan sebagaimana dimaksud pada ayat (8), termasuk menetapkan 1 (satu) pasangan Calon Bupati dan Calon Wakil Bupati serta 1 (satu) Calon Walikota dan Calon Wakil Walikota peserta Pemilihan dalam hal setelah jangka waktu 3 (tiga) hari dimaksud terlampaui namun tetap hanya ada 1 (satu) pasangan Calon Bupati dan Calon Wakil Bupati serta 1 (satu) pasangan Calon Walikota dan Calon Wakil Walikota"

Pasal 51 ayat (2) : Berdasarkan Berita Acara Penetapan sebagaimana dimaksud pada ayat (1), KPU Provinsi menetapkan paling sedikit 2 (dua) pasangan Calon Gubernur dan Calon Wakil Gubernur dengan Keputusan KPU Provinsi, dan menetapkan 1 (satu) pasangan Calon Gubernur dan Calon Wakil Gubernur dalam hal hanya terdapat 1 (satu) pasangan Calon Gubernur dan Calon Wakil Gubernur.

Pasal 52 ayat (2) : Berdasarkan Berita Acara Penetapan sebagaimana dimaksud pada ayat (1), KPU Kabupaten/Kota menetapkan paling sedikit 2 (dua) pasangan Calon Bupati dan Calon Wakil Bupati serta pasangan Calon Walikota dan Calon Wakil Walikota dengan Keputusan KPU Kabupaten/Kota dan menetapkan 1 (satu) pasangan Calon Bupati dan Calon Wakil Bupati serta 1 (satu) Calon Walikota dan Calon Wakil Walikota dalam hal hanya terdapat 1 (satu) pasangan Calon Bupati dan Calon Wakil Bupati serta 1 (satu) pasangan Calon Walikota dan Calon Wakil Walikota

Jika dirunut dalam pertimbangan hukum mengapa MK memaknainya seperti itu, ternyata MK berusaha menegakkan prinsip demokrasi dan kedaulatan rakyat. MK menimbang bahwa Pasal 1 angka 1 UU No. 8 Tahun 2015 menyatakan, 
"Pemilihan Gubernur dan Wakil Gubernur, Bupati dan Wakil Bupati, serta Walikota dan Wakil Walikota yang selanjutnya disebut Pemilihan adalah pelaksanaan kedaulatan rakyat di wilayah provinsi dan kabupaten/kota untuk memilih Gubernur dan Wakil Gubernur, Bupati dan Wakil Bupati, serta Walikota dan Wakil Walikota secara langsung dan demokratis." Makna kedaulatan adalah kekuasaan tertinggi. Kedaulatan atau kekuasaan tertinggi tersebut, menurut Pasal 1 ayat (2) UUD 1945, berada di tangan rakyat dan dilaksanakan menurut Undang-Undang Dasar. Dengan demikian, sebagai pelaksanaan kedaulatan rakyat maka Pemilihan Kepala Daerah haruslah menjamin terwujudnya kekuasaan tertinggi yang berada di tangan rakyat. Oleh karena itu, UU 8/2015, sebagai Undang-Undang yang mengatur Pemilihan Kepala Daerah harus menjamin terlaksana atau terselenggaranya kekuasaan tertinggi yang berada di tangan rakyat sesuai dengan amanat UUD 1945. ${ }^{35}$

Selain harus ada jaminan bahwa Pemilihan Kepala Daerah sebagai wujud pelaksanaan kedaulatan rakyat dapat diselenggarakan. Pasal 18 ayat (4) UUD 1945 juga mengamanatkan bahwa kepala daerah harus dipilih secara demokratis. Kata "dipilih" menunjukkan adanya kontestasi dan kontestasi itu harus diselenggarakan secara demokratis. Dalam konteks Pemilihan Kepala Daerah, salah satu ukuran kontestasi yang demokratis itu adalah penyelenggaraannya harus menjamin tersedianya ruang atau peluang bagi rakyat untuk memanifestasikan kedaulatannya dalam melaksanakan haknya, dalam hal ini baik hak untuk memilih maupun hak untuk dipilih. Dengan kata lain, keharusan terselenggaranya Pemilihan Kepala Daerah sebagai wujud pelaksanaan kedaulatan rakyat itu harus disertai dengan jaminan bahwa pemilihan tersebut diselenggarakan dalam kontestasi yang demokratis dimana hak rakyat selaku pemegang kedaulatan, baik hak untuk dipilih maupun hak untuk memilih, tidak boleh dikesampingkan atau diabaikan, lebih-lebih ditiadakan. ${ }^{36}$

Pemaknaaan kreatif ini berkorelasi dengan dengan ajaran living constitution. Bahkan dalam putusan ini bersemayam ajaran living constitution itu sendiri. Dalam putusannya pun MK menggarisbawahi bahwa tidaklah tepat jika hanya terpaku

${ }^{35}$ Ibid., hlm. 38-39

${ }^{36}$ Ibid., hlm. 39 
pada teks konstitusi melainkan juga pada semangat yang berada di balik teks itu. Hal ini senada dengan apa yang dikatakan oleh Saldi Isra, yang menyatakan:37

Konstitusi adalah teks, yaitu benda mati yang berisi rangkaian kalimat. Meskipun demikian, dari sudut filosofi, konstitusi adalah teks yang "hidup". Karena dari fungsinya, konstitusi harus berisi pasal-pasal yang mampu melewati berbagai zaman. Itulah sebabnya dalam kajian hukum tata negara dikenal istilah "the living constitution".

Dalam ajaran the living constitution, menekankan bahwa dalam menafsirkan konstitusi yang perlu diutamakan adalah perkembangan masyarakat saat ini. Kerancuan makna dari ketentuan yang terkandung dalam konstitusi harus diartikan sesuai dengan keinginan atau kehendak rakyat pada waktu ketentuan konstitusi itu diterapkan. Hal ini juga dikemukakan oleh Keith E. Whittington, bahwa dalam rangka memaknai dokumen dari pendiri bangsa (konstitusi), hakim tidaklah sekadar memaknainya sebagai konstitusi sebuah bangsa saat dokumen itu dibentuk, tetapi juga harus mampu membangun aturan yang baik untuk pemerintahan bangsa tersebut ke depan. ${ }^{38}$

Hal yang demikian beresonansi dengan apa yang dikemukakan oleh Jimly Ashiddiqie bahwa : 39

“Dalam konteks ketatanegaraan, MK dikonstruksikan sebagai pengawal konstitusi yang berfungsi menegakkan keadilan konstitusional di tengah kehidupan masyarakat. MK bertugas mendorong dan menjamin agar konstitusi dihormati dan dilaksanakan oleh semua komponen negara secara konsisten dan bertanggungjawab. Di tengah kelemahan sistem konstitusi yang ada, MK berperan sebagai penafsir agar spirit konstitusi selalu hidup dan mewarnai keberlangsungan bernegara dan bermasyarakat."

Dalam konteks putusan MK di atas, MK melakukan terobosan hukum yang mampu mengatasi persoalan masa kini dengan mengikuti perkembangan yang ada di masyarakat, yaitu fenomena calon tunggal. Terobosan hukum yang dilakukanoleh MK itu berbasis pada makna yang terkandung di dalam Pasal 18 ayat (4) UUD 1945 yang berbunyi “Gubernur, Bupati, dan Walikota dipilih secara

${ }^{37}$ Feri Amsari, Perubahan UUD 1945 Perubahan Konstitusi Negara Kesatuan Republik Indonesia Melalui Putusan Mabkamah Konstitusi, Cet2, Rajawali Pers, Jakarta, 2011, hlm. xvii.

${ }^{38} \mathrm{Ibid}$., hlm. 93

${ }^{39}$ Cetak Biru, Membangun Mabkamah Konstitusi Sebagai Institusi Peradilan Konstitusi yang Modern dan Terpercaya, Sekretariat Jenderal Mahkamah Konstitusi, 2004, yang dikutip dalam Maruarar Siahaan, Hukum Acara Mabkamah Konstitusi Republik Indonesia, Jakarta, Konstitusi Press, 2005, hlm. 12 
demokratis" dimana diterjemahkan bahwa salah satu ukuran kontestasi yang demokratis itu adalah penyelenggaraannya harus menjamin tersedianya ruang atau peluang bagi rakyat untuk memanifestasikan kedaulatannya dalam melaksanakan haknya, dalam hal ini baik hak untuk memilih maupun hak untuk dipilih. Maka, baik terdapat banyak calon ataupun hanya terdapat satu pasangan calon, pilkada harus tetap dilaksanakan untuk memanifestasikan hak untuk memilih (right to be vote) dan hak untuk dipilih (right to be candidate) warga negara. Akhirnya, dapat disimpulkan bahwa Putusan MK-RI Nomor 100/PUU-XIII/2015 merupakan putusan MK yang progresif yang juga melindungi prinsip demokrasi dan hak asasi manusia. Adapun, untuk memudahkan dalam memahami, bisa melihat tabel sebagai berikut:

Tabel. 1.

Progresivitas Putusan MK-RI Nomor 100/PUU-XIII/2015

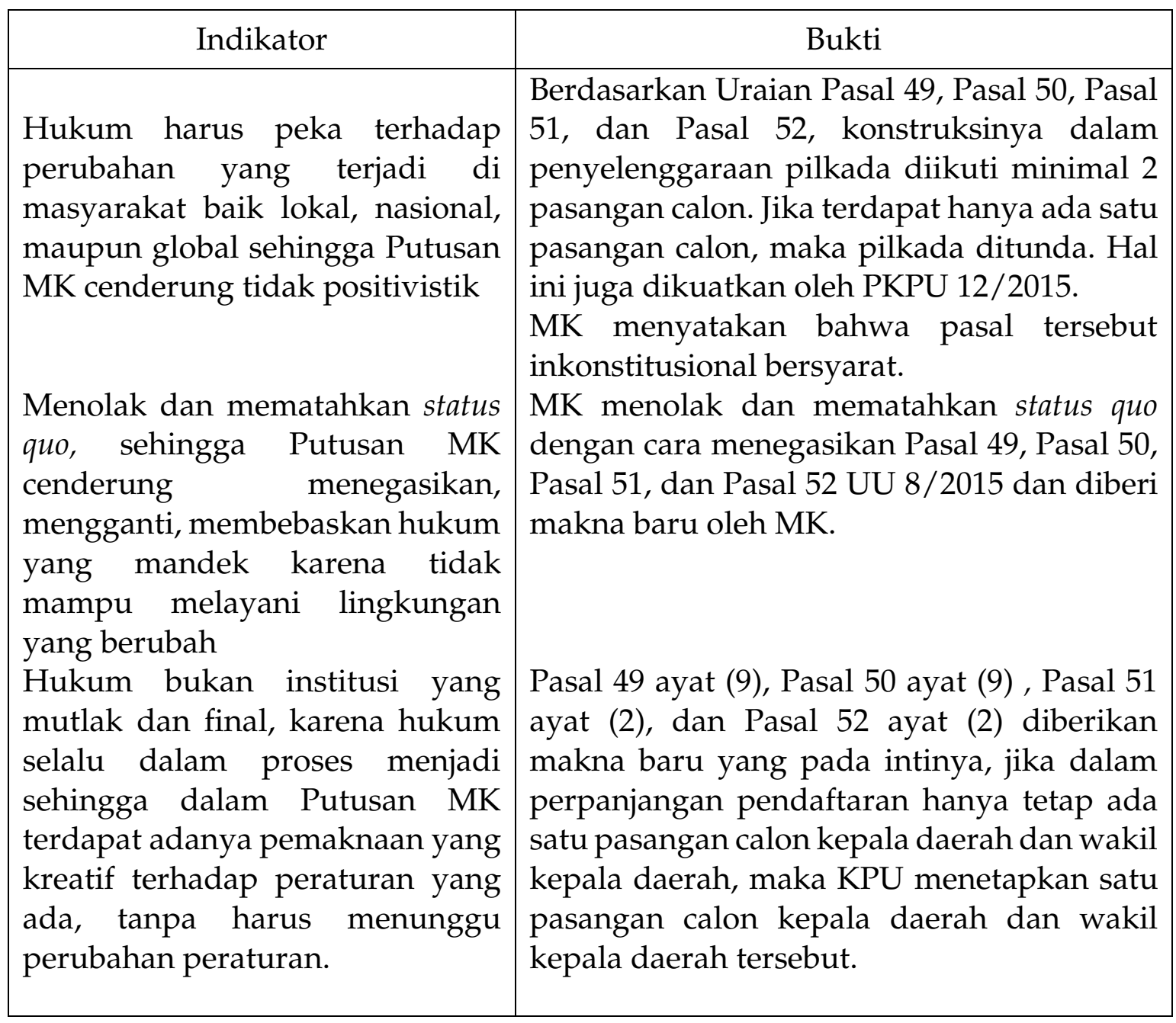


Implikasi Yuridis Putusan Mahkamah Konstitusi Nomor 100/PUU-XIII/2015 Terhadap Pencalonan Kepala Daerah dan Wakil Kepala Daerah

Putusan MK ini memiliki implikasi yuridis terhadap pencalonan kepala daerah dan wakil kepala daerah. Adapun implikasi yuridisnya adalah sebagai berikut : pertama, bahwa jika di suatu daerah terdapat ada calon kepala daerah/wakil kepala daerah dengan hanya satu pasangan calon, maka pilkada tetap di gelar dengan catatan telah diusahakan dengan sungguh-sungguh untuk terpenuhi syarat paling sedikit dua pasangan calon kepala daerah dan wakil kepala. Yang dimaksud dengan "telah diusahakan dengan sungguh-sungguh" adalah telah dilaksanakan ketentuan dalam Pasal 49 ayat (1) sampai dengan ayat (9) UU 8/2015 untuk pemilihan Gubernur/wakil Gubernur dan ketentuan Pasal 50 ayat (1) sampai dengan ayat (9) UU No. 8 Tahun 2015 untuk pemilihan Bupati dan Wakil Bupati/Walikota dan Wakil Walikota. pasca putusan MK. Selanjutnya, secara mutatis mutandis, Pasal 51 ayat (2) UU No. 8 Tahun 2015 dan Pasal 52 ayat (2) UU No. 8 Tahun 2015 maknanya menyesuaikan dengan Putusan MK.Kedua, pemilihan Kepala Daerah dan Wakil Kepala Daerah yang hanya diikuti oleh satu pasangan calon dilakukan dengan memberikan kesempatan kepada rakyat (pemilih) untuk menyatakan "Setuju" atau "Tidak Setuju" dalam surat suara yang didesain sedemikian rupa sehingga memungkinkan rakyat (pemilih) untuk menyatakan pilihan "Setuju" atau "Tidak Setuju" dimaksud. Apabila pilihan "Setuju" memperoleh suara terbanyak maka pasangan calon kepala daerah dan wakil kepala daerah dimaksud ditetapkan sebagai kepala daerah dan wakil kepala daerah terpilih, sedangkan apabila pilihan "Tidak Setuju" memperoleh suara terbanyak maka pemilihan ditunda sampai Pemilihan Kepala Daerah serentak berikutnya. Terhadap poin ini, KPU sudah menindaklanjutinya dengan mengeluarkan peraturan KPU yang mengatur secara teknis penyelenggaraan pilkada dengan daerah yang hanya ada satu pasangan calon (calon tunggal).

\section{Penutup}

Berdasarkan analisis dan pembahasan di atas dapat ditarik kesimpulan sebagai berikut. Pertama, bahwa Putusan MK-RI Nomor 100/PUU-XIII/2015 
terkait Pemilihan kepala daerah dengan hanya satu pasangan calon termasuk putusan yang progresif. Indikasinya adalah : i) Putusan MK tidak positivistik. Berdasarkan uraian Pasal 49-52 UU Pilkada, konstruksinya dalam penyelenggaraan pilkada diikuti minimal 2 pasangan calon. Jika terdapat hanya ada satu pasangan calon, maka pilkada ditunda. Hal ini juga dikuatkan oleh PKPU 12/2015. Realitas yang terjadi, beberapa daerah hanya terdapat satu pasangan calon, atas dasar hal tersebut MK menyatakan bahwa Pasal 49-52 inkonstitusional bersyarat. ii) Putusan MK menolak dan mematahkan status quo dengan cara menegasikan, mengganti, membebaskan hukum yang mandek. Adanya norma Pasal 49-52 menghambat pelaksanaan pilkada dengan hanya satu pasangan calon. iii) berangkat dari asumsi hukum bukan institusi yang mutlak dan final dan hukum selalu dalam proses menjadi sehingga dalam Putusan MK terdapat adanya pemaknaan yang kreatif terhadap peraturan yang ada, tanpa harus menunggu perubahan peraturan. Oleh MK, Pasal 49 ayat (9), diberi makna : KPU Provinsi membuka kembali pendaftaran pasangan Calon Gubernur dan Calon Wakil Gubernur paling lama 3 (tiga) hari setelah penundaan tahapan sebagaimana dimaksud pada ayat (8), termasuk menetapkan 1 (satu) pasangan Calon Gubernur dan Calon Wakil Gubernur peserta Pemilihan dalam hal setelah jangka waktu 3 (tiga) hari dimaksud terlampaui namun tetap hanya ada 1 (satu) pasangan Calon Gubernur dan Calon Wakil Gubernur". Pasal 50 ayat (9) : KPU Kabupaten/Kota membuka kembali pendaftaran pasangan Calon Bupati dan Calon Wakil Bupati serta pasangan Calon Walikota dan Calon Wakil Walikota paling lama 3 (tiga) hari setelah penundaan tahapan sebagaimana dimaksud pada ayat (8), termasuk menetapkan 1 (satu) pasangan Calon Bupati dan Calon Wakil Bupati serta 1 (satu) Calon Walikota dan Calon Wakil Walikota peserta Pemilihan dalam hal setelah jangka waktu 3 (tiga) hari dimaksud terlampaui namun tetap hanya ada 1 (satu) pasangan Calon Bupati dan Calon Wakil Bupati serta 1 (satu) pasangan Calon Walikota dan Calon Wakil Walikota".

Kedua, implikasi yuridisnya, bahwa jika ke depan di suatu daerah terdapat calon kepala daerah/wakil kepala daerah dengan hanya satu pasangan calon, maka pilkada tetap di gelar dengan catatan telah diusahakan dengan sungguhsungguh untuk terpenuhi syarat paling sedikit dua pasangan calon kepala daerah dan wakil kepala. Yang dimaksud dengan "telah diusahakan dengan sungguh- 
sungguh" adalah telah dilaksanakan ketentuan dalam Pasal 49 ayat (1) sampai dengan ayat (9) UU 8/2015 untuk pemilihan Gubernur/wakil Gubernur, sedangkan di tingkat kabupaten atau kota, berlaku ketentuan Pasal 50 ayat (1) sampai dengan ayat (9).Pemilihan dilakukan dengan cara menyatakan "setuju" atau "tidak setuju" dalam kotak suara. Apabila pilihan "Setuju" memperoleh suara terbanyak maka pasangan calon kepala daerah dan wakil kepala daerah dimaksud ditetapkan sebagai kepala daerah dan wakil kepala daerah terpilih, sedangkan apabila pilihan "Tidak Setuju" memperoleh suara terbanyak maka pemilihan ditunda sampai Pemilihan Kepala Daerah serentak berikutnya.

Berdasarkan kesimpulan di atas, peneliti memberikan saran: Pertama, dalam merumuskan pertimbangan hukum dan penjatuhan putusan, spirit hukum progresif hendaknya dapat dijadikan salah satu paradigma dalam memutus suatu perkara. Hakim-hakim konstitusi harus berani menegakkan hukum berspirit hukum progresif untuk mendobrak aturan yang nyata-nyata bertentangan dengan UUD 1945. Kedua, peneliti mengusulkan bahwa tata cara penyelenggaraan pilkada calon tunggal perlu dirumuskan dalam revisi UU 8 Tahun 2015.

\section{Daftar Pustaka}

\section{Buku}

Ali, Mahrus, Membumikan Hukum Progresif, Aswaja Pressindo, Yogyakarta, 2013.

Amsari, Feri, Perubahan UUD 1945 Perubahan Konstitusi Negara Kesatuan Republik Indonesia Melalui Putusan Mahkamah Konstitusi, Cet2, Rajawali Pers, Jakarta, 2011.

Huda, Ni'matul dan R. Nazriyah, Teori \& Pengujian Peraturan Perundang-undangan, Nusa Media, Bandung, 2011.

Rahardjo, Satjipto, Hukum dan Perubahan Sosial : Suatu Tinjauan Teoretis Serta Pengalaman-Pengalaman Di Indonesia, Genta Publishing, Yogyakarta, Cet3, 2009.

Siahaan, Maruarar, Hukum Acara Mahkamah Konstitusi Republik Indonesia, Jakarta, Konstitusi Press, 2005.

Soimin \& Mashuriyanto, Mahkamah Konstitusi Dalam Sistem Ketatanegaraan Indonesia, UII Press, Yogyakarta, 2013.

Syamsudin, M.,, Hukum Progresif, Sebuah Sintesa Hukum Indonesia, Genta Press, Yogyakarta, 2009. 
Membedah Hukum Progresif, Editor I Gede A.B Wiranata, Joni Emirzon, Firman Muntaqo, Penerbit Kompas, Jakarta, 2006.

Penegakan Hukum Progresif, Penerbit Buku Kompas, Jakarta, 2010.

\section{Jurnal}

Syamsudin, M., Kecenderungan Paradigma Berfikir Hakim Dalam Memutus Perkara Korupsi, Jurnal Media Hukum, Vol.15, No.2, Tahun 2008.

\section{Peraturan Peurndang-undangan}

Undang-Undang Dasar Negara Republik Indonesia Tahun 1945

Undang-Undang Nomor 8 Tahun 2015 tentang Pemilihan Gubernur, Bupati, dan Walikota

\section{Putusan Pengadilan}

Putusan Mahkamah Konstitusi Nomor 100/PUU-XIII/2015

\section{Internet}

Tiga Kabupaten Dengan Calon Tunggal, http://print.kompas.com/baca/ 2015/09/30/Kejar-Pilkada-2015\%2c-Tiga-Kabupaten-dengan-Calon-Tu, diakses 28 Maret 2016 